\title{
White Football in South Africa: Empire, Apartheid and Change, 1892-1977
}

\author{
Chris Bolsmann
}

Aston University, Birmingham

This essay traces the development, domination and decline of white football in South Africa. It suggests that white football was more significant and popular than generally acknowledged and was at the forefront of globalizing football in the early twentieth century. In order to better understand the broader history of twentiethcentury South African football, a more detailed examination of the organized white game at the national and international levels is necessary. This historical analysis of elite white football draws from the archives of the Football Association of South Africa. The analysis underscores the important role of white football authorities in the contestation of power and identity in the game in South Africa and abroad. In the first period under consideration (1892-1940s), local football authorities challenged the dominant sports within South Africa. This period was followed in the 1950s by the challenges of professionalism and anti-apartheid organisations. In the final phase (1967-1977), officials experimented with football on 'multi-national' and multi-racial lines-a failed reform that led to the demise of white football.

This essay traces the development, domination and decline of organized white football in South Africa. ${ }^{1}$ It suggests that white football was more significant and popular than generally acknowledged. In order to better understand the broader history of twentieth-century South African football, a more detailed examination of the organized white game at the national and international levels is necessary. ${ }^{2}$ The objective of this analysis is to highlight three main periods of elite white football and reveal a number of contradictions along with the contestation over the game in South Africa. First, between 1892 and the late 1940s, white football players, organizations, and administrators maintained close links with Britain, the Commonwealth and the notion of Empire and were at the forefront of globalizing football. Second, race and politics always played a very prominent role in South African football throughout this period but were particularly influential in the 1950s and 1960s. At the national level white football authorities supported apartheid; internationally, a struggle over

\footnotetext{
*Email: c.h.bolsmann@aston.ac.uk
} 
representation of South Africa abroad ensued. Third, from the late 1960s to 1977, white South African administrators attempted to restructure football along "multinational" (later "multi-racial") lines in order to secure white privilege at home and gain readmission to FIFA. This reform failed and this led to the demise of white football.

\section{Britain, Empire and the Commonwealth}

In the late 1880s and early 1890s provincial football organizations were formed. In 1892 , the whites-only South African Football Association (SAFA) was founded to give the 'dribbling code a stronger place in sport in the country'. ${ }^{3}$ Donald Currie, the shipping magnate, donated trophies to five sports codes in South Africa during the 1880s and 1890s and the football version was first contested in 1892. Cecil Rhodes was made Honorary President of the Association in $1895,{ }^{4}$ with Presidents Paul Kruger of the South African Republic and Francis Reitz of the Orange Free State Republic patrons of the Association. At this time, SAFA applied to the English Football Association (FA) for affiliation and along with New Zealand were affiliated in 1897 . Beck argued that the FA 'sought to help associations, ${ }^{5}$ by permitting affiliation to the FA. However, such affiliation ceased once membership of the international body was obtained. SAFA had a representative based in London, who attended FA meetings and canvassed support for tours to and from Britain.

In 1893 preliminary discussions for a South African tour to Britain were held. ${ }^{6}$ The Corinthian Football Club was the first foreign football team to visit South Africa in 1897. The side played 23 games against white teams and included three 'tests' against South Africa and 5000 spectators watched the first game at the Wanderers Ground in central Johannesburg. All expenses were covered by SAFA. ${ }^{7}$ The Corinthian side visited South Africa again in 1903 and lost their first match to foreign opposition in Durban. In their 1907 tour, the Corinthians lost five, won twelve and drew seven matches in South Africa. While this highlighted the 
improvement of the standard of play in South Africa, it also marked the decline of the Corinthian side due to 'the split' between amateurs and professionals in Britain. ${ }^{8}$

South African teams also travelled abroad in the early days of African football. Most notably, in September 1899, a black football side from the Orange Free State Republic embarked on a tour of Britain and France under the auspices of the (white) Orange Free State Football Association. Thus, a black team was the first South African team to play abroad. Despite (or perhaps because of) the outbreak of the South African War, this tour received significant press coverage in Europe but very little in South Africa. ${ }^{9}$ SAFA re-affiliated to the English FA in 1903 and the Argentine FA did the same in 1904. As a result, the second foreign tour by a South African side was organized. The Argentine FA invited South Africa to play in South America. The South Africans won eleven matches out of twelve, and beat an Argentine league side 4-1 in Buenos Aires (classified as a 'test'), 'Combinados' 6-1 in Montevideo, Uruguay, and the 'Scratch-Team Paulista' 6-0 in São Paulo, Brazil. ${ }^{10}$ South Africa was therefore at the forefront of globalizing football in the early twentieth century.

With the successes of the football side in South America and the rugby side in Britain, coupled with a greater sense of a white South African identity that emerged after the South African War, this informed SAFA's decision to withdraw its affiliation from the English FA in $1907 .{ }^{11}$ That same year, SAFA adopted the olive green jerseys and the Springbok as the badge to be used in test matches. SAFA President Capt. L.L. French proposed a 'central association embracing the British Empire'. ${ }^{12}$ SAFA re-affiliated to the English FA in 1926 and retained membership until South Africa's departure from the Commonwealth in 1961. In 1906 SAFA unsuccessfully tried to affiliate to the International Football Association Board (IFAB) through its imperial connections. The Fédération Internationale de Football Association (FIFA) invited SAFA to join in 1908 and the latter became a member in 1910: the first from outside of Europe. ${ }^{13}$ 
Although SAFA adopted an internationalist approach to football by playing abroad and engaging with the world body, their efforts were primarily focussed on securing a visit by a British team to the country. South Africa became a popular destination for British sides over the next fifty years. The English FA were invited to tour South Africa and SAFA requested a full strength side with a good mix of amateurs. ${ }^{14}$ The English FA representative side (that included professionals and internationals) of 1910 was the first of four before 1939 and of five in total. The English FA sent representative rather than full international sides and still played and won all sixty-six games that included twelve 'tests' against South Africa. This reflected the weakness of the game in the country relative to the successes of South African cricket and rugby sides against foreign opposition. SAFA President A. B. Godbold remarked prior to the 1910 tour that 'it will enable us to know if . . we have in Association Football reached the same high standard which our confreres in the sister code have arrived at ... then it cannot be long before we shall ask "the powers that be" in the Old Country to receive the first South African Soccer team'. ${ }^{15}$ This only occurred in 1924 by which stage the South African rugby team had hosted five British Isles tours and had toured Britain in 1906 and 1912. The English FA's 'long standing missionary desire to promote the game in the face of the challenge from other sports reinforced traditional imperial sentiments'. ${ }^{16}$ SAFA were keen to invite British opposition and the country proved to be a popular destination for the FA who also visited Australia twice, and New Zealand and Canada/United States once during this period. ${ }^{17}$ Beyond the rationale of the 'missionary' zeal to tour abroad, profits were generated for the English FA and indeed the various affiliates of SAFA.

Despite its internationalist tendencies, SAFA looked towards the English FA for guidance in the global sphere. The outbreak of World War One brought a suspension of the annual Currie Cup tournament (resumed in 1922) and the cancellation of an English FA tour planned for 1914. In the annual report of 1916, SAFA remarked that the war had negatively 
affected the game in the country, but that 'we should congratulate our brave players on the decision and sacrifices they have made in the sacred cause ... and [for] the part they have played for our Empire and freedom'. ${ }^{18}$ SAFA's membership of FIFA had lapsed during the war as did that of the British football associations. These associations re-affiliated to FIFA and when South Africa played a game in the Netherlands (where FIFA was based at the time) on their international tour, the possibility of re-affiliation was discussed with the organisation. The 1924 tour of Britain, Ireland and the Netherlands was the first to Europe by a SAFA representative side. Despite good crowds and results, the tour was a financial loss. ${ }^{19}$

The bonds of Empire remained strong after the 1924 tour, despite SAFA temporarily rejoining FIFA in that year. SAFA, however, left FIFA in 1926 when it re-affiliated to the English FA. It proposed the formation of a British Commonwealth Association to the English FA 'whereby Overseas and Dominion tours could be arranged on a uniform basis'. ${ }^{20}$ SAFA hereby revisited an idea first proposed in 1907, and this highlighted the enduring appeal of Empire. In addition, SAFA remarked that they had no voting rights in the English FA and the IFAB made rule alterations without any input from dominion FAs. SAFA canvassed support from other dominions and Australia observed that 'as the interests of our Colonies in the Southern Hemisphere are singularly mutual Australia would treat any steps . . . as progressive'. ${ }^{21}$ Scotland responded to SAFA and stated that while its officials were 'certainly sympathetic . . . [they] were very doubtful as to its practicality'. ${ }^{22}$ SAFA's initiative was part of a broader trend within the Empire where direct political control was replaced by indirect rule in the colonies more informal structures, as seen in the sports arena. The British Empire Games illustrated this development, where new identities were forged while maintaining elements of 'Empire solidarity'. ${ }^{23}$ In taking this action South Africa began to play an important role internationally and her sports organizations saw themselves as equal partners in Empire. 
By the late 1920s, SAFA still had ambitions for football to become the most popular game amongst white South Africans. At the SAFA AGM of 1928, French remarked that,

progress of the game has not been satisfactory ... sport is the national factor of lives of the people of this and every country ... is worth playing and worth supporting as a national characteristic of South Africa. We agree that our game of soccer appeals and deserves to appeal to a large section of the population both white and coloured . . . it has no inferiority complex when compared with any other game or sport...The game itself deserves to be supported, it is played by people of different colour, nationality, and religion, in nearly every country in the world ... the fact that the game is excluded from playgrounds of many Universities, Colleges and Schools in South Africa is unfortunate and regrettable. ${ }^{24}$

Despite its seemingly non-racial overtones, the Constitution and Rules of SAFA clearly stated that members had to be 'of full European descent'. ${ }^{25}$ SAFA's global engagement was envisioned first and foremost through membership in the British Empire rather than the French-led internationalism embodied in FIFA.

In 1946 the English FA requested SAFA's views on affiliation with FIFA. SAFA stated that it 'did not wish to affiliate directly but would prefer to remain a sub-ordinate part of the Football Association'. ${ }^{26}$ This again demonstrated SAFA's reluctance to engage internationally but rather to attempt to exert influence within Empire football. During the 1948 Olympic Games held in London, an Empire Football Associations meeting was held. Australia had initiated the meeting, which was attended by delegates from England, Scotland, Ireland, Wales, Australia, Canada, New Zealand, South Africa, West Indies, British Guiana, Trinidad and Jamaica. The British FAs declared they would consider sending "British" teams . . . to tour the Dominions annually,. ${ }^{27}$ All the associations expressed the desire that amateur sides visit their respective countries, with the exception of South Africa which 'wanted only the best Professional teams to visit us', ${ }^{28}$ perhaps harbouring the illusion that they could compete against such teams and generate profits. Prior to World War Two, South 
Africans began to play football in Britain and SAFA increasingly looked towards Britain for tours to generate income and improve the standard of the game at home.

\section{Tours, Profits and Professionalism}

In the late 1920s the first foreign professional club sides visited South Africa. They generally proved too strong for local opposition. Nevertheless, SAFA were able to gauge the standard of the local game while they generated profits for the associations and regional organizations, particularly those in Natal and the Transvaal. In 1927 Aberdeen FC were the first foreign professional club to visit South Africa. Motherwell visited in 1931 and 1934 and Aberdeen toured again in 1937. SAFA declared that 'the Executive is of the opinion that the claims of the Dominions and the Overseas' Associations should have preference over foreign Associations at present, and that it will be some considerable time before it will be possible to invite any Continental teams to tour South Africa'. ${ }^{29}$ SAFA not only shunned FIFA for the English FA, they also preferred British opposition to continental European sides. A number of continental sides requested permission to play in South Africa but were turned down by SAFA. This suggests SAFA saw football developing similarly to rugby in the Anglophone world, and that such teams would not provide stern enough opposition and would offer poor financial returns. The tours of the 1920s and 1930s barely made profits and the standard of the representative teams was relatively poor. In 1930, a Transvaal representative side and Arcadia from Pretoria visited Lourenço Marques in Portuguese East Africa (Maputo, Mozambique). Sides from Lourenço Marques played matches in Johannesburg, Pretoria and Witbank in the early 1930s. Such reciprocal visits occurred until the early 1970s. The possibility of the Associação de Futebol de Lourenço Marques' affiliation to SAFA was discussed by the South African association, although nothing came of this. 
In 1931, SAFA received an invitation from the Dutch East Indies FA to travel to Java for a series of matches. It was noted that, 'playing against non-Europeans: (Should not prevent acceptance of tour)'. ${ }^{30}$ However, SAFA refused to play against 'non-European' opposition in South Africa, as was the case in 1934 when an Indian football team toured the country. ${ }^{31}$ The President of the South African Indian Football Association, Albert Christopher, was quoted in the press stating: 'all men are equal in the sovereignty of sport. I hope South African sportsmen will rise above all racial considerations and play the All-India team at least one match' ${ }^{32}$ Despite Christopher's idealistic exhortations, the whites refused to play against the tourists from India. This contradiction meant SAFA were prepared to play against 'non-European' opposition abroad but not at home and this would remain the case until the late 1960s. The Vienna Athletic Club were the first continental European team to play in South Africa in 1936. SAFA stated that 'their exhibition had been disappointing ... [and] it is doubtful whether the experiment should again be attempted unless a guarantee of the very best is fulfilled'. ${ }^{33}$ This highlighted the concerns SAFA had raised with regards to non-British opposition.

In 1947 the bonds of Empire were strengthened when a South African side toured Australia and New Zealand, and again in 1950 when Australia toured South Africa. However, South Africa began to engage with countries outside of the Empire and by the early 1950s SAFA looked towards the European continent for opposition. In 1951, for example, SAFA invited Belgium, France, the Netherlands, Norway, Portugal and Sweden to tour the country, but all declined the invitations as other matches had been scheduled. An English FA representative side toured southern Africa in 1956.

Over the next decade many overseas teams visited southern Africa; these included Athletic Club of Portugal and Wolverhampton Wanderers (1951), Newcastle United (1952), Dundee United and Israel FA (1953), Hearts of Midlothian (1953/54), Djurgården (1956), 
Dynamo Club Prague and Wolverhampton Wanderers (1957), Ajax Amsterdam, Preston North End and Sandvikens (1958), Bolton Wanderers (1959), Leicester City (1961), A.C. Cerro and Tottenham Hotspur (1963), Arsenal, Eintracht Frankfurt and Real Madrid (1964). In most cases these sides were too strong for local white opposition, but the tours generated profits for foreign sides and the local association.

South Africa also sent all-white teams abroad in the first decade of apartheid. A Natal representative side toured Mauritius in 1951 and 1955 and played against mixed black and white sides in front of 20,000 spectators. ${ }^{34}$ Combined white club sides Marists/Rangers and Arcadia/Berea Park competed in La Ligue Royale de Football du Katanga tournaments in Elisabethville (today Lubumbashi) and Jadotville (Likasi), Belgian Congo (Democratic Republic of Congo) in 1957 and 1958 respectively. ${ }^{35}$ Crowds of 20,000 spectators watched the South Africans play against mixed black and white sides from Katanga and Ferroviaro (Beira). ${ }^{36}$ South Africa also toured Britain, the Netherlands, and Portugal in 1958. The Portuguese under $24 \mathrm{~s}$ fielded 'three capable coloured players' against South Africa in a match played in front of a crowd of 30,000 in Lisbon. ${ }^{37}$ This evidence reveals a contradiction: all-white South African club, provincial and national sides competed against racially mixed sides in front of mixed crowds abroad, but refused to do so at home.

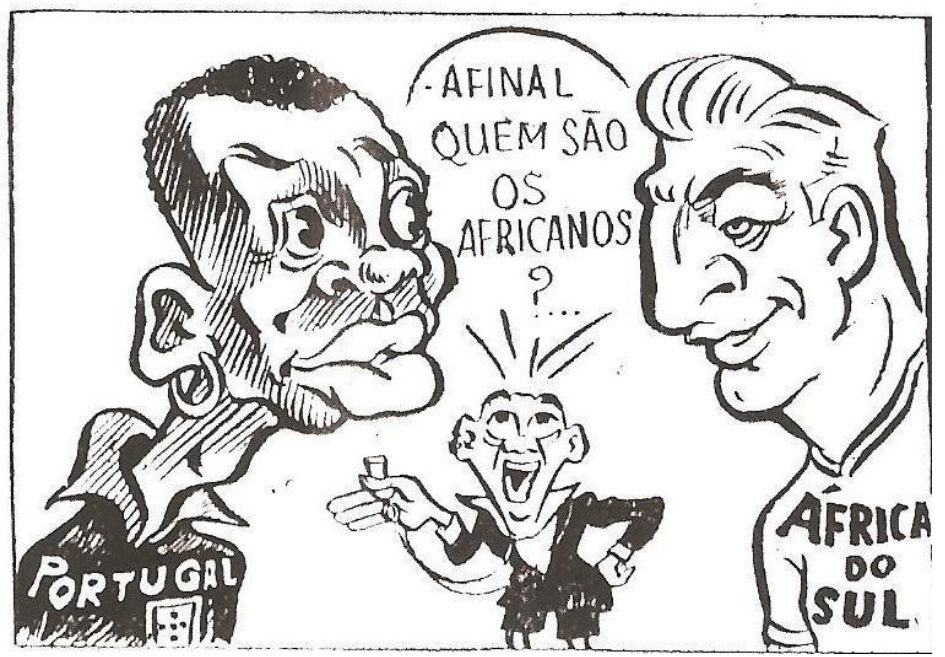


'Who are the Africans?'Note the racial stereotyping and caricature. (Diario de Lisboa, 17 November 1958)

Along with the attraction of tours, professionalism became an issue for SAFA. Since the 1930s, when a number of white South Africans were playing football in Britain, SAFA expressed concern about professional football. SAFA president, Fred Fell wrote in 1939 that, 'this is a problem we must face ... It is not my intention to stem the flow of players in this country taking up Professional football as a career, but merely to regulate it. ${ }^{38}$ Large numbers of South Africans moved to Europe to play professionally in the 1950s and towards the end of 1958 preparations were made by Queens Park in Durban for a team of professional South Africans based overseas to visit the country. ${ }^{39}$ The Football Association of Southern Africa (FASA, SAFA's new name adopted in 1957 as per discussion below) refused permission because such tours were permitted only if organized by provincial associations. ${ }^{40}$ In 1959, FASA appointed a committee and commission of enquiry into 'malpractices, and sham amateurism' and professional football. ${ }^{41}$ In the same year the whites-only professional National Football League (NFL) was established and applied for affiliation to FASA. The FASA committee reported that 'professional football can only be of benefit . . the consensus of public and officials is of opinion that South African [white] football is in the doldrums'. ${ }^{42}$ The reasons for this were low attendance and poor results against international sides. FASA's constitution was amended to include professionals and the NFL and the South African Bantu Football Association (SABFA) were affiliated to the body. SAFA's co-option of black football associations was aimed to protect their FIFA status and attempt to control all football in South Africa. ${ }^{43}$ FASA's AGM of 1961 reported that in terms of professional football 'there is no doubt it was a great success ... the Clubs and players wanted it, the public seemed to want it ... there is no reason why soccer eventually will not be the national game of South Africa' ${ }^{44}$ In the eighteen years of its existence, the NFL received generous sponsorships from 
companies like South African Breweries, United Tobacco Companies, Coca-Cola, British Petroleum and Sanlam. Some prominent British players represented NFL sides, such as Billy Wright, Stanley Matthews, Tom Finney and even George Best. The NFL remained a whitesonly league with segregated stadiums and, in certain instances, a whites-only attendance policy. Even so, Cape Town City, Durban City and Highlands Park attracted a surprising number of black supporters. ${ }^{45}$ Within the context of apartheid South Africa, FASA and the NFL strictly adhered to government policy while internationally this position was increasingly challenged.

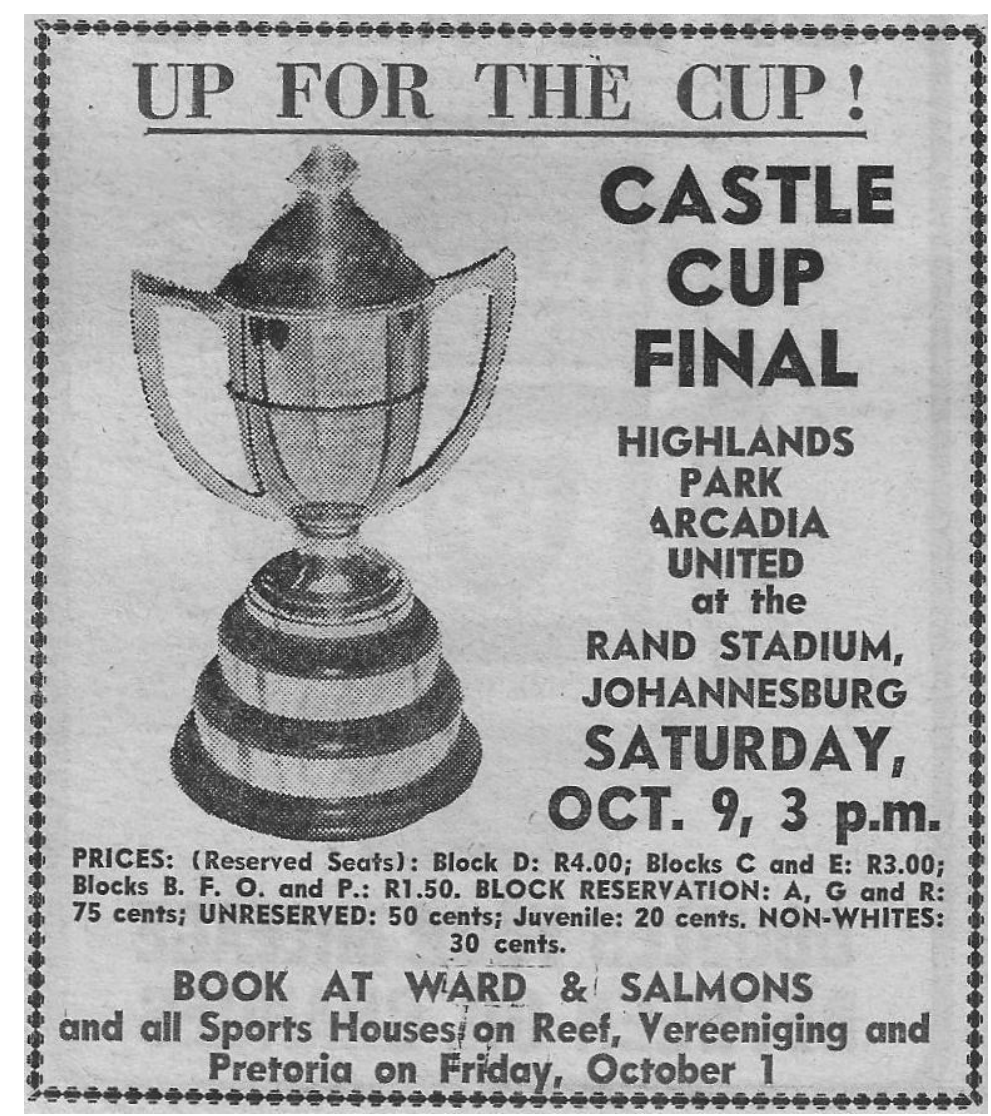

Castle Cup Final 1965 sponsored by South African Breweries. Note the different entry prices. (South African Footballer, 24 September 1965). 


\section{Race, Politics and the South African Game in a Global Context}

The late 1950s and early 1960s represented the golden age of white football as a number of foreign sides visited South Africa, the NFL's popularity increased and the white game became a marketable commodity that challenged rugby as the pastime of choice for white South Africans. This occurred against the backdrop of increased national and international protests and campaigns to isolate white sports organizations and bring change to the country. In June 1951, SAFA reapplied for FIFA membership. It was granted and ratified at the 1952 Helsinki congress. However, SAFA's right to represent South African football in the world body was challenged by the anti-apartheid South African Soccer Federation (SASF). This body was formed in September 1951 by the South African African Football Association (founded in 1932), South African Coloured Football Association (1933) and the South African Indian Football Association (1903). In March 1952, SASF wrote to SAFA and inquired whether they would accept 'an application for affiliation . . . to your body' or if SAFA would 'consider linking up with SASF' ${ }^{46}$ In August 1952, the SASF applied to FIFA for membership and stated 'that [this] body has no race or colour restrictive rules and is in fact open to all races' ${ }^{47}$ In its reply, FIFA informed SASF that only one national association could be a member of FIFA. In their communiqué to SAFA, FIFA officials observed that, 'We were in the opinion that the $[\mathrm{SAFA}] \ldots$ was the only autonomous association governing football ... Would this mean your association is not entirely independent and autonomous body controlling football? ${ }^{48}$ At a SAFA Special General Meeting in October 1952 the officers forwarded for discussion several constitutional amendments. Among the most important amendments under consideration was a proposal to retain the racist rule restricting membership to "Europeans," but adding this clause: "save such affiliated members who cater for and control Non-European Football Associations, and whose Constitutions have been approved by this Association' ${ }^{49}$ SAFA paternalistically informed SASF that it "was 
contemplating amending its Constitution to enable your Federation under its wings ... there will obviously be no necessity for your Federation to apply for affiliation to F.I.F.A' ${ }^{50}$ But in the end, this proposed amendment was withdrawn and the racist clauses in the SAFA constitution were only removed in 1956 due to pressure from FIFA.

In June 1954 SASF applied again to FIFA for affiliation and wrote that SAFA 'does not embrace all sections of the South African population'. ${ }^{51}$ In a letter to FIFA SAFA criticised SASF for alleged 'impertinence' and 'impudence' of SASF. According to L.J. Simpson, SAFA’s Honorary Secretary:

My association is the only governing Body for Europeans . . . there is a clear line of demarcation between Europeans and Non-Europeans (called Apartheid) in this Country. According to the Laws of South Africa there is no intermingling between Europeans, and Non-Europeans either Socially or particularly on the field of Sport. In Sporting activities Europeans, and Non-Europeans do not, and never have participated in the same Competitions ... . [we] are still prepared to allow the S.A. Soccer Federation to affiliate to our Association . . . subject to the Laws of this Country. All Associations affiliated to my Association cater for and provide special stands for NonEuropeans at reduced prices for European matches. ${ }^{52}$

SAFA offered membership without voting rights to SASF and added that it would not permit any breach of the laws of the country, such as integrated football. ${ }^{53}$ In January 1954 SASF rejected SAFA's offer and observed that the proposal 'will involve our acceptance of racial and colour discrimination in the field of sport' and 'to our knowledge no legislation exists prohibiting mixed play between White and non-White races in this country' ${ }^{54}$ SASF proposed a Supreme Council that would control football, represent South Africa in FIFA, and select a non-racial national team. The struggle between SAFA and SASF was waged over the definition and meaning of 'South Africa' represented by a whites-only policy versus that of non-racism and integration.

The struggle between SAFA and SASF played itself out at FIFA. The world body was initially sympathetic towards SAFA and the status quo in South Africa. An Emergency 
Committee Meeting of FIFA in May 1955 recognized that SAFA 'does not comprise and control all the clubs and players in South Africa ... [and] therefore [does] not [have] the standing of a real National Association'. However, it also agreed with SAFA that the 'fusion' of the two Associations 'clashes with the Laws and customs of the country'. ${ }^{55}$ FIFA proposed the formation of a 'South African Interfederal Committee' that would liaise with FIFA. SASF accepted the principle of a 'Governing Body', but SAFA would not agree to an Interfederal Committee as 'the Government of South Africa would under no circumstances authorise or allow the Federation to become an equal Member or Partner of my Association' ${ }^{56}$ FIFA then informed SAFA and SASF that a delegation would visit South Africa. The FIFA delegation visited South Africa in January 1956 under the leadership of the Dutchman Karel Lotsy. The commission's report insisted SAFA remove the racist clauses in its constitution. But it also pointed out that football 'does not play the big role as elsewhere. Rugby is the sport $\mathrm{nr} 1$ [sic] . . c care must therefore be taken with the game in the future. It is absolutely necessary that the present administration of the game be left unchanged' and to 'replace [SAFA] ... would retrogade [sic] football in South Africa' ${ }^{57}$ The delegation suggested SASF affiliate to SAFA 'as an autonomous section'. ${ }^{58}$ SAFA accepted the Lotsy Commission's recommendation to remove the racist provisions regarding members and referees from the SAFA constitution. ${ }^{59}$ At the 1956 Lisbon Congress of FIFA, Lotsy reported that 'we may not forget that it is not the S.A.F.A., which refuses to allow Non-Europeans to play for South Africa. It is the unwritten law of the country! 60

In June 1956, South Africa's Minister of the Interior, T. E. Dönges, issued the regime's first sport policy through the media. Dönges declared that sport would remain segregated and that inter-racial competitions were prohibited in South Africa. Dönges also warned that, 'non-European sport organisations seeking international recognition must do so through the aegis of white Associations already enjoying such benefits'. ${ }^{61}$ In March 1957 
SAFA become the Football Association of Southern Africa (FASA) and retained the Springbok as the national badge. The new name was meant to create the impression of significant change in the organisation of football. ${ }^{62}$

In 1958 SASF challenged FASA to go against apartheid policy. SASF asked FASA to select a representative side to play against the SASF; permit 'non-White' players to join FASA clubs; select 'non-White' players for tours abroad; consider the selection of 'nonWhites' for games against foreign opposition in South Africa; permit 'non-White' players in Rhodesia to join white clubs, and whether white sides from South Africa could play against mixed sides in Rhodesia. ${ }^{63}$ FASA responded defensively:

[It] would be a contravention of the Law . . . it would not permit non-Whites players playing for European Clubs in South Africa . . . teams of South African Europeans would be permitted to play against mixed Clubs in Rhodesia subject to Government approval ... when European teams from South Africa play in Rhodesia there would be no objection to such European teams playing against mixed clubs. This has in fact been the established policy of my Association for some considerable time past. As an example, when South African European teams visit Lourenço Marques or the Belgium Congo or similar territories, there has never been any objection to such teams playing against Non-European teams or mixed teams in those areas. ${ }^{64}$

FASA asked Dönges whether, 'notwithstanding the fact that there is no specific Law prohibiting matches between Europeans and Non-Europeans, does the Department favour matches of this nature or matches between teams composed of Europeans and NonEuropeans? [and] would the Government, if necessary, take all steps to insure the observance of the South African traditional way of life in regards to matches of this Nature? ${ }^{65}$ The Department of the Interior answered unambiguously: 'Definitely not [and] Yes, that is the policy of the Department' ${ }^{66}$ Rather than consider the SASF proposal, FASA's correspondence with the minister highlighted its position and complacency in relation to apartheid. 
The struggle against apartheid football not only played itself out at FIFA but was also contested at the continental level. At the Berne 1954 FIFA Congress, African delegates were able to secure representation on the executive body of FIFA. ${ }^{67}$ Dave Snaier, the SAFA delegate to Berne was contacted by Abdel Aziz Abdallah Salem, the Egyptian delegate to FIFA, who 'informed him that he was in the process of preparing a suggested Constitution for submission to all the African Associations for consideration'. ${ }^{68}$ SAFA met with Salem during FIFA's 1956 visit to South Africa and 'it was agreed that a Meeting of all Associations on the African Continent should be arranged'. ${ }^{69}$ SAFA's Fred Fell and delegates from Egypt and Sudan met to discuss the matter in Lisbon in June 1956. The Confédération Africaine de Football (CAF) was officially launched in Khartoum the following year with four founding members: Egypt, Ethiopia, South Africa and Sudan. 'A constitution and Bye-laws were drawn up and agreed upon and it was decided to hold the first Tournament in Khartoum during the first week in February 1957 . . Fell stated that South Africa would enter a team. ${ }^{70}$ The Rand Daily Mail wrote in October 1956 that 'South Africa has promised to send a team to Khartoum (Sudan) next February to take part in the first-ever Pan-African soccer tournament [and] the Springboks to fly on from Khartoum to Europe'. ${ }^{71}$ In this inaugural African Cup of Nations, South Africa was scheduled to play against Ethiopia. ${ }^{72}$ SAFA intended to extend the tour, provided 'satisfactory financial arrangements could be made'. ${ }^{73}$ At a FASA Special General Meeting participation in the Khartoum tournament was moved and seconded with Western Province voting against participation. 'Permission was granted [to] the Executive to spend whatever money was necessary' ${ }^{74}$ However, SAFA contacted the Sudanese FA with regards to the 'International situation in North Africa [Suez Crisis] . . . suggesting the competition be either cancelled or postponed'. ${ }^{75}$ In a cable reply from the Sudanese FA it was confirmed that the tournament would go ahead: 'now confirm playing on dates already fixed no change ... dates of African Competition stand good' ${ }^{76}$ SAFA argued 
that, 'the officers have carefully considered the matter and it was agreed to advise the Sudan F.A. that owing to the time factor and the International situation in North Africa and the Middle East our entry for the African Cup Competition is withdrawn' ${ }^{77}$ The Rand Daily Mail wrote that, 'because of the unsettled situation in the Middle East and North Africa [SAFA] has reluctantly withdrawn from the competition'. The report also noted that participation 'was not received in the Union with much enthusiasm in the first place'. ${ }^{78}$ Nevertheless, Fell attended the CAF meeting in February 1957 and he 'reported that the Meeting was mostly concerned with drawing up the Rules for the future running of the African Cup competition which will take place every four years' ${ }^{79}$ Thus South Africa did not participate in the first African continental competition, ostensibly because of the Suez crisis, although CAF claimed FASA refused to send a racially mixed side to compete in the tournament. ${ }^{80}$

Snaier attended the CAF meeting on 4 June 1958 in Stockholm and reported that FASA would enter a side in the 1959 African Cup of Nations. ${ }^{81}$ FASA decided to undertake a tour of Israel, Greece and Turkey after the tournament. Fell declared that 'there was no objection to Europeans, and Non-Europeans playing matches outside the Union of South Africa' ${ }^{82}$ But in April 1959, SAFA informed CAF that due to the visit by Bolton Wanderers 'it was impossible to enter a team' in the second African Cup of Nations. ${ }^{83}$ FASA also informed CAF that it would not attend the CAF meeting prior to the FIFA Congress in Rome in 1960. FASA was expelled from CAF at the Rome meeting. ${ }^{84}$ This represented a victory for the anti-apartheid struggle in sport and provided further impetus to take this forward to FIFA and to pursue the expulsion of FASA from the international body. FIFA's 1960 Rome Congress passed a resolution that national associations could not practice racial, religious or political discrimination. FASA was given 12 months to abide by the resolution. ${ }^{85}$

The white establishment in South Africa remained intransigent. The Minister of the Interior, Johannes de Klerk, told FASA that if South Africa were expelled from FIFA, then 
SASF officials would be denied passports, tours abroad, and the chance to invite foreign teams. De Klerk stated that:

[while ] there is no legislation in this country prohibiting inter-racial competition ... [and] whilst the Government is sympathetic towards and prepared to help non-White sporting associations which accord with the Government's policy of separate development it will not support non-White sporting activities designed to force the country to abandon the South Africa custom that Whites and non-Whites should organize their activities, in whatever field, separately . . . Competitions between White and non-White teams within the Republic, will . . . not be tolerated, nor will passport facilities be extended to teams composed of Whites and non-Whites, or teams from abroad, so composed, be allowed to enter the Republic. There is no objection, though, that a non-White team from South Africa competes against a White team abroad'. ${ }^{86}$

South Africa's unwillingness to change its racist stance forced FIFA to suspend FASA in September 1961. Vivian Granger, NFL General Manager and its representative at FASA, moved that foreign sides be permitted to play against 'non-European' teams and 'that a multi-racial game should be arranged' between FASA and 'the non-European Associations' ${ }^{87}$ Moreover, Granger suggested that 'a multi-racial game should be organized, in order to test the Government's sincerity in respect to their attitude towards such games ... if such a game was stopped by the Government, then the publicity emanating . . . would prove invaluable [in relation to FIFA] ${ }^{88}$ FASA Vice-President Snaier worried that this modest proposal would be unacceptable to Pretoria and perhaps even illegal. However, in early 1962 FASA permitted a black-white match in Maseru, Lesotho. Black Pirates lost to the NFL's Germiston Callies (0-3) in front of 9,000 spectators. ${ }^{89}$

The absurdity of apartheid football was evident when Granger proposed to FIFA President Stanley Rous that a FASA 'non-White' side enter the 1966 and a white side the 1970 World Cup qualifying stages. ${ }^{90}$ A FASA delegation comprising Fell, Dave Marais and Bethuel P. Morolo (SABFA) attended the 1962 FIFA Congress in Chile. Fell reported to FASA that 'Mr. Morolo's main duty was to mix as much as possible with the Afro-Asian 
delegates and explain the position of his association with the FASA'. ${ }^{11}$ The SABFA collaborated with FASA and in turn represented the establishment rather than the alternative of non-racial sport. In November 1962, FASA dropped Southern in its name and replaced this with South after Southern and Northern Rhodesia were no longer affiliated to the body and the first meeting of four members of FASA and the SABFA known as the 'Top-Level Committee' took place. In 1963 an Indian and a Coloured Association (recent FASA affiliates) joined the committee. In January 1963, a FIFA delegation comprised of Stanley Rous and James McGuire visited South Africa. In their official report they came to the surprising conclusion that 'there is no wilful discrimination on the apart of the F.A.S.A. in respect to any Organisation ... and if the suspension is not lifted ... the progress of the game ... will be retarded'. ${ }^{92}$ As a result of this report, the suspension of FASA was temporarily lifted. Rous's stance towards FASA and apartheid South Africa cost him the FIFA presidency the following decade..$^{93}$

During the brief respite from isolation in 1963-64, South Africa entered the draw for the qualifying rounds of the 1966 World Cup grouped with Australia, North Korea and South Korea. FASA was concerned with the financial implications of playing in this "Pacific" Asian group and FIFA suggested that the games could be played in Australia at no cost to the associations. Incredibly, FASA intended to field a 'non-European' team (coached by Englishman Jack Gibbons) against the 'non-white countries' and a white side against Australia!' The South African government agreed to issue travel documents for the "nonWhite' side 'provided that the team be under white supervision whilst overseas'. ${ }^{95}$ Press reports suggested the South African side could even be 'mixed' ${ }^{96}$ FASA asked the Ministry of the Interior whether it would 'agree to matches taking place outside the Republic of South Africa being played on a multi-racial basis? ${ }^{97}$ The response from the government was clear: 'a multi-racial South African team cannot . . be be approved'. ${ }^{98}$ Despite Granger's and FASA's 
hopes that the participation of a 'non-European' side in the World Cup qualifying matches would strengthen FASA's case, FIFA suspended FASA at the 1964 Tokyo Congress. FASA's preparations for the 1966 World Cup were called off.

Apartheid sport was dealt a major blow when South Africa was not invited to participate in the 1968 Mexico City Olympic Games. In football, FASA's Marais and the Rhodesian FA Honorary Secretary G. Kerr discussed the formation of a white-run Southern African Confederation to counteract the growing political clout of CAF within FIFA. ${ }^{99}$ Preparatory meetings were scheduled for Johannesburg and Salisbury (Harare), but Rous observed that FIFA would not recognise such a grouping as CAF was in existence. As part of the Swaziland's independence celebrations, the Swazi Government arranged a match to be played in September 1969 in the country between Orlando Pirates and Highlands Park. Due to FASA's suspension and Swaziland not being a FIFA member FIFA permitted the game to take place. However, in August 1969 the South African government banned participation. Marais stated that the cancellation was 'a terrible blow to us . . as we had hoped to convince F.I.F.A that the white footballers in this country would welcome the opportunity of playing against anybody, no matter what their colour or creed'. ${ }^{100}$ With apartheid South Africa increasingly isolated from world sport, Pretoria changed strategy.

\section{"Multi-nationalism," Expulsion from FIFA and White Football's Decline}

Prime Minister John Vorster's policy of 'multinationalism' (introduced in 1967) was

intended as a response to the ostracism of South Africa from global sport. ${ }^{101}$ Under this policy, teams of racially defined 'nations' would be allowed to compete against one another, and possibly together against foreign opposition. ${ }^{102}$ FASA tinkered with multinationalism with the purpose of projecting an image of substantive change abroad (especially to FIFA), while maintaining control and privilege at home. In September 1971, it requested all 
divisional associations canvass opinions on multi-racial football. At FASA's 1972 AGM it was reported that $70 \%$ of the affiliates had agreed in principle to playing multi-racial football. FASA informed FIFA that the Associations favoured the selection of national sides on merit. ${ }^{103}$ FASA affiliates were against multi-racial football at certain levels, particularly at club and junior levels (including schools). This stance exposed the limits of superficial change while the status quo was maintained.

In 1972 FASA began preparations for the South African Games which were to include amateur international sides (the South African Government had given permission for these sides to be mixed) and multi-national (i.e. racially defined) South African teams. FIFA gave a 'special dispensation' ${ }^{104}$ for a football tournament to take place at the Games. Brazil and England provisionally accepted invitations to send amateur international sides with FASA covering all financial costs. FIFA requested additional information from FASA about whether teams would be racially mixed and whether stadiums would be segregated. ${ }^{105}$ FASA replied that South African teams would be selected on a racial basis and that stadiums would be segregated. FIFA immediately withdrew its approval and wrote: 'we regret the executive was misled and wrongly interpreted the term "multi-racial". ${ }^{106}$ Despite the withdrawal of international sporting bodies' support, the 1973 South African Games went ahead. The South African "Whites" twice beat the "Blacks" in football. In 1974, the Embassy Multinational Series tournament between racially defined sides was staged, and in 1975 the Chevrolet 'Champion of Champions' pitted black and white clubs against one another. ${ }^{107}$ The latter tournament was organized by the Top Level Committee, generated significant profits and was watched by substantial crowds, which suggested racially mixed football was popular.

The growing success of the sports boycott against South Africa added pressure to expel FASA from FIFA. FASA acknowledged that multinational football had not brought any change and Marais suggested to the Minister of Sport, Piet Koornhof, that '[we] use 
soccer as the guinea pig for experimenting with multi racial sport'. ${ }^{108}$ In 1975, Marais suggested to FASA that it 'should gradually be expanded into a multi racial body [to include] a multi racial Executive'. ${ }^{109}$ In the months that led up to the FIFA 1976 Montreal Congress, FASA sent letters to 70 associations in French, German and Spanish canvassing support. A glossy brochure with photos of 'White and non-White players enjoying the game together' was published in four languages. ${ }^{110}$ FIFA sent a three-person delegation to South Africa which recommended that the suspension remain in effect and the establishment of an overall football organisation in the country. The delegation watched a match between a racially mixed South Africa Invitation XI and an Argentine XI. In Montreal, Harold Thompson of the English FA and Marais spoke out against the resolution in which 78 of the 104 members voted in favour of FASA's expulsion. This was important in the context of the Soweto uprising as apartheid increasingly came under the spotlight.

As one of the consequences of FASA's expulsion, the Football Council of South Africa was formed. George Thabe, of the South African National Football Association and National Professional Football League, was elected President. The 'basic aim of the Council is to establish and control normal and unrestricted football at all levels in South Africa'. ${ }^{111}$ In a frank address to the FASA AGM in 1977, the President, Ian Taylor, stated that, 'from the blacks' point of view we must be prepared to admit that we have shown prejudice to them, we have obtained the best facilities and we have organized overseas tours and visits to their exclusion. All this is admitted but we must now show that it is our earnest desire to change all this so that we can normalise our sporting relationships'. ${ }^{112}$

Adding to the gloom of the 1977 AGM, it was reported that the NFL had suffered 'a disastrous year in many respects'. ${ }^{113}$ Attendances were down, the NFL lost income for the first time; Datsun-Nissan withdrew its annual R50,000 sponsorship and the Football Council's Mainstay League Cup attracted a number of NFL sides. ${ }^{114}$ At a meeting between 
FASA and SASF held in April 1978, FASA 'accepted the basic principle of non-racial soccer from grass-roots level' ${ }^{115}$ But it was too little too late.

\section{Conclusion}

The expulsion from FIFA, the demise of the NFL, the emergence of the Football Council and the start of non-racial professional football in South Africa, marked the decline of elite white football. FASA was increasingly marginal in the domestic game, focusing primarily on amateur and junior football through the 1980s until the formation of the racially integrated South African Football Association in December 1991 and the readmission of South Africa into FIFA in July 1992.

This historical analysis of the development, domination and decline of elite white football underscores the important role of white football authorities in the contestation of power and identity in the game in South Africa and indeed internationally. Clearly, white football was significant and popular. In the first period under consideration (1892-1940s), local football authorities attempted to challenge the more dominant sports within South Africa by promoting tours and engaging with the English FA, Commonwealth members and FIFA. This period was followed in the 1950s and 1960s by the challenges of professionalism and the attempts to generate profits from overseas tours. Opposition to apartheid in sport from non-racial football administrators meant white football authorities were no longer the sole representatives of South Africa internationally. FASA's acceptance of the apartheid status quo led to its initial suspension and ultimate expulsion from the world body. In the final phase (1967-1977) in accordance with evolving government policy, white officials experimented with football on multi-national and multi-racial lines. However, by this time, developments within black football in South Africa and world opinion undercut Pretoria's superficial attempts at reforming apartheid. 


\section{Notes}

${ }^{1}$ In any analysis of South Africa a consideration of the use of racial categories and terminology is necessary. The Population Registration Act of 1950 and subsequent amendments classified South Africans as African, Coloured, Indian and White. In addition, a range of derogatory racial terms were used. These include the terms 'Bantu', 'Kaffir', 'Native', 'non-European', and 'non-White' amongst others. For the purposes of this analysis I have used these words in direct quotations and the term Black to include African, Coloured and Indian South Africans. This essay draws from the archives of the Football Association of South Africa. Negotiations are underway for these to be deposited in the Historical Papers, William Cullen Library, University of the Witwatersrand, Johannesburg.

${ }^{2}$ With thanks in particular to Peter Alegi, Paul Darby, Marlene Gerber, Mark Gleeson, Lloyd Hill, Richard Maguire, Colin Trader and Tony Wilcocks who offered their time, advice, sources and insights. All interpretations are mine.

${ }^{3}$ Diamond Field Advertiser 6 October, 1892.

${ }^{4}$ The Cape Argus 14 August 1894.

${ }^{5}$ Beck, Scoring for Britain, 58.

${ }^{6}$ Birmingham Daily Post 25 January 1894.

${ }^{7}$ The Sportsman 27 March 1897; Natal Witness 27 August 1898.

${ }^{8}$ Creek, A History; Cavallini, Play Up.

${ }^{9}$ The 'Kaffir Football Team' played 47 games (Won 1, Drew 1, Lost 45) in England, Scotland, Ireland, Wales and France. See Bolsmann, 'The 1899 Orange Free State Football team tour of Europe: race, sport and spectacle', unpublished paper.

${ }^{10}$ The Buenos Aires Herald, 17 July 1906; Platnauer, Sport; El Dia 18 Julio 1906; O Estado de São Paulo 31 de Julio de 1906.

${ }^{11}$ The Friend 23 August 1907.

${ }^{12}$ Ibid.

${ }^{13}$ FIFA, Minutes of the $7^{\text {th }}$ Annual Congress, Milan, 15-16 May 1910.

${ }^{14}$ SAFA, AGM, 16 August 1909.

${ }^{15}$ South African Rugby Board and South African Football Association. Official Souvenir.

${ }^{16}$ Beck, Scoring for Britain, 106.

${ }^{17}$ Beck, Scoring for Britain.

${ }^{18}$ SAFA, Annual Report, 24 July 1916.

${ }^{19}$ The FA presented to SAFA an identical trophy to the one given to the Australian FA and Canadian FA. The trophy was used for the annual school tournament and known as the Football Association Challenge Trophy introduced in 1927.

${ }^{20}$ SAFA, Meeting, 10 August 1929.

${ }^{21}$ SAFA, AGM, 30 August 1929.

${ }^{22}$ SAFA, Meeting, 18 September 1929. 
${ }^{23}$ Moore, The Warmth, 209.

${ }^{24}$ SAFA, AGM, 24 August 1928.

${ }^{25}$ SAFA, Circular to Divisional Associations, 1 February 1930.

${ }^{26}$ SAFA, Letter to English FA, 22 March 1946.

${ }^{27}$ SAFA, Report from Fred Fell, 30 July 1948.

${ }^{28}$ Ibid.

${ }^{29}$ SAFA, Meeting, 16 March 1929.

${ }^{30}$ SAFA, Meeting, 4 September 1931.

31 'All-India' won 14 and lost 1 game.

32 ‘Mr. Hofmeyer welcomes All-India team’ Indian Opinion 22 June 1934 p271.

${ }^{33}$ SAFA, Annual Report, 1936.

${ }^{34}$ Brown, Ha'Pence, 54; The Natal Daily News 7 November 1955.

${ }^{35}$ For a discussion of the first sub-Saharan African football championship in Katanga see Alegi 1999.

${ }^{36}$ L'Essor du Congo 19, 23 \& 24 Juillet 1958; The Pretoria News 16 \& 23 July 1958.

${ }^{37}$ The Natal Daily News 17 November 1958 p16.

${ }^{38}$ Fred Fell address to SAFA AGM, 4 March 1939.

${ }^{39}$ Raath, 2002 suggests 150 South Africans played in Britain between the end of World War Two and the 1960s.

${ }^{40}$ The Natal Daily News 6 November 1958.

${ }^{41}$ FASA, Minutes of Executive Meeting, 7 March 1959.

${ }^{42}$ FASA, Confidential Report on Professional Football, n.d.

${ }^{43}$ Alegi, Laduma!, 114.

${ }^{44}$ FASA, AGM, 4 March 1961.

${ }^{45}$ For a discussion of black professional football see Alegi, Laduma!, 117-135.

${ }^{46}$ SASF, Letter to FASA, 29 March 1952.

${ }^{47}$ SASF, Letter to FIFA, 19 August 1952.

${ }^{48}$ FIFA, Letter to SAFA, 28 August 1952.

${ }^{49}$ SAFA, Minutes of Special General Meeting, 11 October 1952.

${ }^{50}$ SAFA, Letter to SASF, 4 November 1952.

${ }^{51}$ SASF, Letter to FIFA, 10 June 1954.

${ }^{52}$ SAFA, Letter to FIFA, 20 September 1954. 
${ }^{53}$ SAFA, Letter to SASF, 21 November 1954.

${ }^{54}$ SASF, Letter to SAFA, 18 January 1955.

${ }^{55}$ FIFA, Letter to SAFA and SASF, 29 June 1955.

${ }^{56}$ SAFA, Letter to FIFA, 20 August 1955; Minutes of Meeting, 4 July 1955.

${ }^{57}$ FIFA, Report, 2 March 1956.

${ }^{58}$ Ibid.

${ }^{59}$ SAFA, Minutes of Special General Meeting, 3 March 1956.

${ }^{60}$ Karel Lotsy, Report about the football-situation in South Africa.

${ }^{61}$ FASA, Letter to SASF, 4 November 1957.

${ }^{62}$ Alegi, Laduma! 113.

${ }^{63}$ SASF, Letter to FASA, 22 February 1958.

${ }^{64}$ FASA, Letter to SASF, n.d.

${ }^{65}$ FASA, Letter to Minister of the Interior D.T. Donges, 26 May 1958.

${ }^{66}$ Department of the Interior, Letter to FASA, n.d.

${ }^{67}$ Darby, Africa, 34.

${ }^{68}$ SAFA, Minutes of Meeting, 26 October 1954.

${ }^{69}$ SAFA, Minutes of Meeting, n.d.

${ }^{70}$ SAFA, Minutes of Executive Meeting, 22 June 1956.

71 'Rangers' European Tour Offered to S.A.F.A' Rand Daily Mail 29 October 1956.

${ }^{72}$ SAFA, Minutes of Meeting, 16 August 1956.

${ }^{73}$ SAFA, Minutes of Executive Meeting, 26 October 1956.

${ }^{74}$ SAFA, Minutes of Special General Meeting, 27 October 1956.

${ }^{75}$ SAFA, Minutes of Meeting, 27 December 1956.

${ }^{76}$ Ibid.

${ }^{77}$ Ibid.

${ }^{78}$ S.A. Out of Khartoum Tournament: Now Rangers can Ask for Tour of Europe'. Rand Daily Mail 29 December 1956.

${ }^{79}$ SAFA, Minutes of the Executive Meeting, 1 March 1957.

${ }^{80}$ Mahjoub, F (ed) Confederation Africaine de Football Association 1957-1997, Cairo: Nubar Printing House. Thanks to Peter Alegi and Paul Darby for this reference.

${ }^{81}$ SAFA, Minutes of Half Yearly Meeting, 1 November 1958.

${ }^{82}$ Ibid. 
${ }^{83}$ FASA, Minutes, 14 and 16 April 1959.

${ }^{84}$ Alegi, Laduma!, 117.

${ }^{85}$ see Alegi, Laduma!, 117 and Darby, Africa, 73.

${ }^{86}$ Ministry of the Interior, Letter to FASA, 20 June 1960.

${ }^{87}$ FASA, Minutes of FASA Half-Yearly Meeting, 18 November 1961.

${ }^{88}$ Ibid.

${ }^{89}$ The Star 26 February 1962.

${ }^{90}$ Vivian Granger, Letter to Stanley Rous, 27 August 1962.

${ }^{91}$ Fred Fell, Report to FASA.

${ }^{92}$ Stanley Rous and James McGuire, Report.

${ }^{93}$ Darby, Stanley Rous, 2008.

${ }^{94}$ FASA, Letter to the Minter of the Interior, 27 February 1964.

${ }^{95}$ Ministry of the Interior, Letter to FASA, 12 March 1964.

${ }^{96}$ FIFA Plan for World Cup, The Star 1 April 1964.

${ }^{97}$ FASA, Letter to the Ministry of the Interior, 7 April 1964.

${ }^{98}$ Ministry of the Interior, Letter to FASA, 20 April 1964.

${ }^{99}$ G. Kerr, Letter to Dave Marais, 24 December 1968.

${ }^{100}$ Marais, Draft letter to Stanley Rous, 21 August 1969.

${ }^{101}$ Merrett, If Nothing Else.

102 Alegi, Laduma!; Archer and Bouillon, The South African; Booth, The Race Game.

${ }^{103}$ FASA, AGM, 11 March 1972.

${ }^{104}$ FIFA, Letter to FASA, 26 January 1973.

${ }^{105}$ FIFA, Letter to FASA, 28 November 1972.

${ }^{106}$ FIFA, Telegram to Dave Marais, n.d.

${ }^{107}$ Alegi, Laduma!, 141-2.

${ }^{108}$ FASA, Minutes of the Executive, 10 August 1974

${ }^{109}$ FASA, Minutes of the Executive, 7 March 1975.

${ }^{110}$ FASA, Letter, 15 January 1976.

${ }^{111}$ Football Council of South Africa, Letter to FIFA, 1 December 1976; Thabe, It's a Goal.

${ }^{112}$ FASA, AGM President's Report, 12 Match 1977. 
${ }^{113}$ FASA, AGM Minutes, 12 March 1977.

${ }^{114}$ Ibid.

${ }^{115}$ FASA, Minutes of Officers Meeting, 1 April 1978.

\section{References}

Alegi, P. 'Katanga vs Johannesburg: a History of the First Sub-Saharan African Football Championship, 1949-1950.' Kleio 31 (1999): 55-74.

Laduma! Soccer, Politics and Society in South Africa. Scottsville: University of KwaZulu-Natal Press, 2004.

Archer, R. and Bouillon, A. The South African Game: Sport and Racism. London: Zed Press, 1982.

Beck, P.J. Scoring for Britain: International Football and International Politics, 19001939.London: Frank Cass, 1999.

Bolsmann, C. 'The 1899 Orange Free State Football team tour of Europe: race, sport and spectacle', unpublished paper.

Booth, D. The Race Game: Sport and Politics in South Africa. London: Frank Cass, 1998.

Brown, T. More Kicks Than Ha'Pence. Durban: C.G. Brown n.d.

Creek, F. A History of the Corinthian Football Club. London: Longmans, Green \& Co, 1933.

Cavallini, R. Play up Corinth: A History of the Corinthian Football Club. Chalford Stroud: Stadia, 2007.

Darby, P. Africa, Football and FIFA: Politics, Colonialism and Resistance. London and Portland, OR: Frank Cass, 2002.

'Stanley Rous's 'Own Goal': Football Politics, South Africa and the Contest for the FIFA Presidency in 1974.' Soccer \& Society 9, no.2 (2008): 259-272.

Mahjoub, F. (ed.). Confederation Africaine de Football Association 1957-1997, Cairo: Nubar Printing House, 1997. 
Merrett, C. “"In Nothing Else are Deprivers so Deprived”: South African Sport, Apartheid and Foreign Relations, 1945-71.' International Journal of the History of Sport 13, no. 2 (1996): 146-165.

Moore, K. "“The warmth of Comradeship": The First British Empire Games and Imperial Solidarity' in The Cultural Bond: Sport, Empire, Society. Mangan, J.A. (ed). London: Frank Cass, 1992.

Plautner, E.J.L. (ed). Sport and Pastime in the Transvaal. Johannesburg: Geo Wunderlich, 1908.

Raath, P. Soccer Through the Years, 1862-2002. Cape Town: P. Raath, 2002.

South African Rugby Board and South African Football Association. Official Souvenir of the British Rugby and Association Football Tours 1910, L.A. Cox and F.G. Pay: Cape Town, 1910.

Thabe, G.A.L. (ed.). It's a Goal! 50 Years of Sweat, Tears and Drama in Black Soccer. Johannesburg: Skotaville, 1983. 